\title{
A TRAINING BY USING GOOGLE MEET FOR ELEMENTARY SCHOOL TEACHERS
}

\author{
Gustiana \\ SDN 009 Pekantua, Indragiri Hilir, Riau, Indonesia \\ gustiana009@yahoo.com
}

ABSTRACT

This Covid outbreak greatly affects the education that supports the 4.0 revolution era by bringing changes in learning in Indonesia. Teachers conduct distance learning (PJJ) through Google Meet as an alternative provided by the principal in improving learning in the classroom. Increasing the teachers' ability is inseparable from the role of a school principal by providing various trainings that are able to be followed by teachers. This study used the action research method using 2 cycles of enforcement involving 11 teachers. The results of the research showed that the score on the teachers ability to make applications was 63 meaning that the level of success was quite good, while in cycle II, the average score increased to 80 with good category. Furthermore, the average score of the teacher's ability to implement google meet in learning in cycle I was 65 with good category and it increased in Cycle II to 80.5 with a good category. Thus, it was concluded that the teacehrs' ability increased after holding the training.

Keywords: training, google meet

\section{PELATIHAN MENGGUNAKAN GOOGLE MEET BAGI GURU SEKOLAH DASAR}

\begin{abstract}
ABSTRAK
Wabah covid ini sangat mempengaruhi kepada factor pendidikan yang mendukung kepada era revolusi 4.0 dengan membawa perubahan-perubahan dalam pembelajaran di Indonesia. Pembelajaran jarak jauh (PJJ) yang akan digunakan oleh guru dengan menggunakan plafon google meet sebagai salah satu alternative yang mampu diberikan oleh kepala sekolah dalam meningkatkan pembelajaran di kelas. Peningkatan kemampuan guru tidak terlepas dari peran seorang kepala sekolah dengan memberikan berbagai pelatihan yang mampu diikuti oleh guru. Penelitian ini menggunakan metode penelitian Tindakan dengan menggunakan pemberlakukan sebanyak 2 siklus dengan jumlah guru 11 orang dengan hasil penelitian kemampuan guru dalam membuat aplikasi sebesar 63 kualifikasi keberhasilan cukup baik, sedangkan pada siklus ke II dengan rata-rata 80 dengan kualifikasi keberhasilan kategori baik. Sedangkan dalam kemampuan guru dalam mengimplementasi google meet dalam pembelajaran pada siklus I dengan rat-rata 65 dengan kualifikasi keberhasilan baik, pada siklus II dengan rata-rata 80.5 dengan kategori baik. Sehingga dapat disimpulkan bahwa kemampuan guru mengalami peningkatan pada tingkat kemampuan guru dengan diadakannya pelatihan.
\end{abstract}

Kata Kunci: pelatihan, google meet

\begin{tabular}{|c|c|c|}
\hline Submitted & Accepted & Published \\
\hline 10 Februari 2021 & 11 April 2021 & 25 Mei 2021 \\
\hline
\end{tabular}

\begin{tabular}{|l|l|l|l} 
Citation & $:$ & Gustiana, G. (2021). A Training by Using Google Meet for Elementary School Teachers. Jurnal PAJAR (Pendidikan dan \\
\hline
\end{tabular} Pengajaran), 5(3), 772-777. DOI : http://dx.doi.org/10.33578/pjr.v5i3.8393.

\section{PENDAHULUAN}

Covid-19 adalah penyakit menular yang disebabkan oleh jenis coronavirus yang baru ditemukan. Walaupun lebih banyak menyerang ke lansia, virus ini sebenarnya bisa juga menyerang siapa saja, mulai dari bayi, anak-anak, hingga orang dewasa. Virus corona ini bisa menyebabkan ganguan ringan pada sistem pernapasan, infeksi paru-paru yang berat, hingga kematian (Harnani,
2020). Beberapa pemerintah daerah memutuskan menerapkan kebijakan untuk meliburkan siswa dan mulai menerapkan metode belajar dengan sistem daring (dalam jaringan) atau online. Pemanfaatan berbagai media pembelajaran jarak jauh (PJJ) yang harus dikuasai oleh guru dengan menggunakan berbagai plafon yang mendukung sesuai dengan kemampuan dan keinginan guru 
(Dhiatmika, 2020). Plafon seperti google meet merupakan media komunikasi untuk melaksanakan pembelajaran secara daring dengan memberikan kemudahan bagi guru dalam membuatnya.

Wabah covid ini sangat mempengaruhi kepada factor pendidikan yang mendukung kepada era revolusi 4.0 dengan membawa perubahanperubahan dalam pembelajaran di Indonesia (Subekti, 2018). Pembelajaran jarak jauh (PJJ) yang akan digunakan oleh guru dengan menggunakan plafon google meet sebagai salah satu alternative yang mampu diberikan oleh kepala sekolah dalam meningkatkan pembelajaran di kelas. Peningkatan kemampuan guru tidak terlepas dari peran seorang kepala sekolah dengan memberikan berbagai pelatihan yang mampu diikuti oleh guru. Saat ini peran teknologi berkembang yang akan berimbas kepada gaya hidup (Kurniaman et al., 2020) menjadikan lebih fleksibel, lebih cepat, dan tidak bisa dihindari sesuai pada tingkat umur atau usia (Islam, 2019) sehingga sangat penting seorang guru untuk melek teknologi (Kurniaman, Hidayat, Noviana, Munjiatun, \& Kurniawan, 2020).

Peran kepala sekolah dengan memberikan pelatihan kepada guru tentang pembelajaran google meet yang merupakan pembelajaran yang menggunakan jaringan internet dengan aksesibilitas, konektivitas, fleksibilitas, dan kemempuan yang untuk memunculkan berbagai interaksi pembelajaran (Sadikin, dan Hamidah, 2020). Penggunaan internet dan teknologi multimedia mampu merombak cara penyampaian pengetahuan dan menjadikan salah satu alternative pembelajaran yang dilakukan oleh guru untuk menghindari penyebaran virus covid 19 (Zhang et al., 2004). Pembelajaran dengan menggunakan google meet merupakan pembelajaran daring yang mampu memberikan interaksi guru dan siswa dengan bantuan internet sebagai pengantar dalam kegiatan pembelajaran (Kuntarto, 2007). Dalam tatanan pembelajaran daring dengan menggunakan google meet ini membutuhkan dukungan siswa dalam mempersiapkan perangkat mobile seperti smartphone, laptop, computer, tablet yang mampu mengakses pembelajaran dimana pun berada (Gikas \& Grant, 2013; Darmalaksana, 2020; He \& Kruck, 2014) pembelajaran daring ini merupakan pendukung pembelajaran berbesis revolusi 4.0.

\section{METODE PENELITIAN}

Penelitian ini menggunakan metode penelitian tindakan dengan dilakukan 2 siklus yang sering disebut penelitian tindakan sekolah karena subjek penelitian yang difokuskan kepada guruguru di SDN 009 Pekantua Kecamatan Kempas Kabupaten Indragiri Hilir dengan jumlah 11 orang guru. Penelitian tindakan menekankan kepada kegiatan (tindakan) dengan mengujicobakan suatu ide ke dalam praktik atau situasi nyata dalam skala mikro yang diharapkan tindakan tersebut mampu memperbaiki, meningkatkan kualitas dan melakukan perbaikan sosial (Zuriah, 2003; Rambe, 2019). Pelaksanaan penelitian tindakan yang akan dilakukan ini terdiri dari empat tahapan, yang meliputi perencanaan, pelaksanaan tindakan, pengamatan dan refleksi. Pelaksanaan penelitian yang digunakan berbentuk siklus (Juliana, 2018).

Teknik pengumpulan data dalam penelitian ini menggunakan Teknik observasi dan penilaian kemampuan guru dalam mengaplikasikan google meet sebagai media pembelajaran yang akan digunakan untuk proses pembelajaran. Teknik analisis data yang digunakan menggunakan rumus :

$\mathrm{NR}=\frac{R}{S M} \times 100$

Keterangan:

$\mathrm{NR}=$ Nilai Kemampuan

$\mathrm{R}=$ Jumlah yang di dapat

$\mathrm{SM}=$ Skor yang didapat

Setelah diperoleh dengan menggunakan rumus di atas maka nilai kemampuan guru diklasifikasikan sesuai dengan tabel 1 sebagai berikut: 
Tabel 1. Penilaian Kemampuan Guru

\begin{tabular}{cc}
\hline Interval & Kualifikasi \\
\hline $85-100$ & Sangat Baik \\
$65-84$ & Baik \\
$55-64$ & Cukup Baik \\
$0-54$ & Kurang \\
\hline
\end{tabular}

\section{HASIL DAN PEMBAHASAN}

Penelitian ini dilakukan dengan observasi terhadap kemampuan guru di SDN 009 Pekantua terhadap penggunaan aplikasi google meet. Seorang kepala sekolah harus lebih cepat ganggap atas kekurangan yang diperoleh oleh guru sehingga perlu dilakukan penelitian dengan memberikan pelatihan. Kondisi pembelajaran daring saat ini sangat ditekankan seorang guru harus menguasai teknologi yang digunakan dengan berbagai plafon pembelajaran salah satunya dengan menggunakan pembelajaran menggunakan google meet. Sehingga kemampuan guru setelah dilakukan pelatihan akan terlihat setiap siklusnya seperti pada tabel 2 di bawah ini.

Tabel 2. Kemampuan Guru dalam Membuat Aplikasi

\begin{tabular}{clcc}
\hline No & \multicolumn{1}{c}{ Kriteria } & Siklus I & Siklus II \\
\hline 1. & Pembuatan aplikasi google meet & 57 & 70 \\
2. & Mampu mengirim link kepada siswa & 60 & 80 \\
3. & Mampu mengirim PPT sebagai bahan persentasi & 65 & 80 \\
4. & Mampu menggunakan aplikasi google meet & 70 & 90 \\
& Rata-rata & $\mathbf{6 3}$ & $\mathbf{8 0}$ \\
& Kualifikasi Keberhasilan & Cukup Baik & Baik \\
\hline
\end{tabular}

Sesuai dengan tabel 2 di atas bahwa kemampuan guru dalam membuat aplikasi google meet, mengirim link pada siswa, mengirim PPT sebagai bahan persentasi dan menggunakan aplikasi google meet pada siklus I kualifikasi keberhasilannya cenderung cukup baik. Selanjutnya pada siklus ke II kemampuan guru dalam membuat aplikasi google meet, mengirim link pada siswa, mengirim PPT sebagi bahan presentasi dan menggunakan aplikasi google meet mengalami peningkatan pada tiap-tiap kriterianya, sehingga didapatkan kualifikasi keberhasilannya adalah baik.

Tabel 3. Kemampuan Guru dalam Mengimplementasi dalam Pembelajaran

\begin{tabular}{|c|c|c|c|}
\hline No & Nama Guru & Siklus I & Siklus II \\
\hline 1. & Guru 1 & 70 & 80 \\
\hline 2. & Guru 2 & 65 & 75 \\
\hline 3. & Guru 3 & 60 & 80 \\
\hline 4. & Guru 4 & 70 & 85 \\
\hline 5. & Guru 5 & 77 & 90 \\
\hline 6. & Guru 6 & 80 & 95 \\
\hline 7. & Guru 7 & 58 & 70 \\
\hline 8. & Guru 8 & 50 & 70 \\
\hline 9. & Guru 9 & 50 & 75 \\
\hline 10. & Guru 10 & 65 & 80 \\
\hline 11. & Guru 11 & 70 & 85 \\
\hline \multirow{2}{*}{\multicolumn{2}{|c|}{$\begin{array}{c}\text { Rata-rata } \\
\text { Kualifikasi Keberhasilan }\end{array}$}} & 65 & 80.5 \\
\hline & & Baik & Baik \\
\hline
\end{tabular}


Sesuai dengan tabel 3 di atas bahwa, kemampuan dari 11 guru yang mengimplentasi pada pembelajaran dalam siklus I mendapatkan kualifikasi keberhasilan yang baik dengan nilai rata-rata 65 poin. Kemudian kemampuan guru dalam mengaplikasikan pada pembelajaran dalam siklus II juga mendapatkan kualifikasi keberhasilan baik dengan nilai rata-rata yang lebih tinggi, yaitu 80.5 poin. Ini menunjukkan bahwa ada peningkatan rata-rata dari siklus I ke siklus II sebesar 15.5 poin.

Guru memiliki posisi professional untuk memberikan layanan ahli dan memiliki keterampilan akademis, pedagogis, sosial, dan professional dalam menunjang pembelajaran yang bermutu di kelas (Hamdu, \& Yulianto, 2018). Kepemimpinan kepala sekolah merupakan faktor utama dalam meningkatkan kualitas keberhasilan akademis di sekolah (Hallinger, 2007; Ibrahim, Ghavifekr, Ling, Siraj, \& Azeez, 2014; Aydin, Savier, \& Uysal, 2013; Leithwood \& Mascall , 2008). Bahwasannya gaya kepemimpinan di sekolah kepala sekolah juga menjadi katalisator yang membentuk keberhasilan sekolah dengan memberikan berbagai pelatihan, dan bimbingan kepada guru sehingga guru lebih professional. Selain itu juga, banyak dari berbagai penelitian yang menekankan peran penting pemimpin dalam sekolah dalam memastikan keseimbangan struktur system pendidikan (Ling, Abdul Ghani, \& Fairuz, 2015; Earley \& Fletchel-Campbell, 1989; Loo, \& Ling, 2018).

Dalam pembelajaran sesuai dari teori pendidikan bahwa yang pertama kali menunjukan minat dalam pengalaman dalam belajar anak-anak adalah guru di dalam kelas. Kurikulum akan berjalan apabila guru menjalankan dalam proses pembelajaran yang menitik beratkan dalam tema belajar (Chan, 2012; Gideon, 2018) untuk menunjang itu semua tidak terlepas juga dari kepala sekolah yang sangat mengetahui dalam proses belajar mengajar sehingga mampu mengembangkan kemampuan profesionalnya (Witherell \& Noddings, 1991; Clandinin \& Connelly, 1999; Miller, 2005; Craig, 2006). Keberhasilan suatu lembaga pendidikan sangat tergantung pada kepemimpinan Kepala Sekolah. Berkat kepemimpinan dilembaganya, maka dia harus mampu membawa lembaganya ke arah tercapainya tujuan yang telah ditetapkan, dia harus mampu melihat adanya perubahan serta mampu melihat masa depan dalam kehidupan globalisasi yang kebih baik. Kepala Sekolah harus bertanggung jawab atas kelancaran dan keberasilan semua urusan pengaturan dan pengelolaan sekolah secara formal kepada atasannya atau secara informal kepada masyarakat yang telah menitipkan anak-anak didiknya (Marno, 2007).

Kepala Sekolah sebagai penentu kebijakan di sekolah juga harus memfungsikan perannya secara maksimal dan mampu memimpin sekolah dengan bijak dan terarah serta mengarah kepada pencapaian tujuan yang maksimal demi meningkatkan kualitas dan mutu pendidikan di sekolahnya yang tentu saja akan berimbas pada kualitas lulusan anak didik sehingga membanggakan dan menyiapkan masa depan yang cerah (Munir, 2008). Oleh karena itu, Kepala Sekolah harus mempunyai wawasan, keahlian manajerial, mempunyai karisma kepemimpinan dan juga pengetahuan yang luas tentang tugas dan peran sebagai Kepala Sekolah. Dengan kemampuan yang dimiliki seperti itu, Kepala Sekolah tentu saja akan mampu mengantarkan dan membimbing segala komponen yang ada di sekolahnya dengan baik dan efektif menuju ke arah cita-cita sekolah.

\section{SIMPULAN DAN REKOMENDASI}

Simpulan dalam penelitian ini adalah pembelajaran dengan menggunakan pembelajaran daring saat ini dipengaruhi oleh wabah covid-19 sehingga seorang guru perlu sekali menguasai salah satu plafon pembelajaran yang khususnya menggunakan google meet sehingga kepala sekolah wajib membuat kebijakan dengan mengadakan pelatihan tentang google meet dari dua siklus yang dilakukan maka terjadi peningkatan terhadap kemampuan guru dilihat pada aspek membuat aplikasi dan mengimplementasikan dalam proses pembelajaran. Yang menjadi rekomendasi terhadap pelatihan ini sebaiknya selalu diaplikasikan karena apabila tidak dilakukan pembelajaran akan mudah cepat lupa. 


\section{DAFTAR PUSTAKA}

Aydin, A., Savier, Y., \& Uysal, S. (2013). The effect of school principals' leadership styles on teachers' organizational commitment and job satisfaction. Educational Sciences: Theory and Practice, 13(2), 805-811.

Clandinin, D. J., \& Connelly, F. M. (1999). Storying and restoring ourselves: Narrative and reflection. In A-Y Chen, \& J. Van Maanen (Eds.), The reflective spin: Case studies of teachers in higher education transforming action (pp. 15-24). Farrer Road, Singapore: World Scientific.

Chan, E. Y. (2012). The Transforming Power of Narrative in Teacher Education. Australian Journal of Teacher Education. 37 (3): 9.

Craig, C. (2006). Why is dissemination so difficult? The nature of teacher knowledge and thespread of curriculum reform. American Educational Research Journal, 43(2), 257-293.

Darmalaksana, W. (2020). WhatsApp Kuliah Mobile . Fakultas Ushuluddin UIN Sunan Gunung Djati Bandung.

Dhiatmika, N. W. A. (2020). Pembelajaran Jarak Jauh (PJJ) selama Masa Pandemi Covid-19. [online] 8 April 2021. https://www.sma1sukawati.sch.id/berita/5fc3326c6131645f460 003bb/pembelajaran-jarak-jauh-pjj-selamamasa-pandemi-covid19.

Earley, P., \& Fletcher-Campbell, F. (1989). Managing school departments and faculties: towards better practice. Educational Research, 31(2), 98-112.

Gikas, J., \& Grant, M. M. (2013). Mobile computing devices in higher education: Student perspectives on learning with cellphones, smartphones \& social media. Internet and Higher Education. https://doi.org/10.1016/jijheduc.2013.06.002.

Gideon, A. A. (2018). Teachers' Familiarity and Opinion on Utilization of Narrative Recollection Technique in Basic Schools in Nigeria. International Journal Of Innovative Research \& Development, 7(12), 37-42. DOI No. : 10.24940/ijird/2018/v7/i12/OCT18028.

Hallinger, P. (2007). Leadership for Learning: Reflections on the practices of instructional and transformational leadership. Paper presented at Seminar at East Asia University. Harnani. (2020). Efektivitas Pembelajaran Daring Di Masa Pandemi Covid-19. [online] 8 April 2021.

https://bdkjakarta.kemenag.go.id/berita/efekti vitas-pembelajaran-daring-di-masa-pandemicovid-19.

He, W., Xu, G., \& Kruck, S. (2014). Online IS Education for the 21st Century . Journal of Information Systems Education.

Hamdu, G., \& Yulianto, A. (2018). The Ability of Prospective Elementary School Teachers to Develop Student Worksheets on ContextBased Science Learning. Mimbar Sekolah Dasar, 5(3), 155-161. doi:http://dx.doi.org/10.17509/mimbarsd.v5i3.14503

Islam, P. S. (2019). Perkembangan Teknologi dan Pengaruhnya terhadap Penggunanya. [Online] $16 \quad$ Mei 2020. https://www.kompasiana.com/putrisuryaisla $\mathrm{m} / 5 \mathrm{dd} 2 \mathrm{ca} 75097 \mathrm{f36260936d522/per}$ kembangan-teknologi-dan-pengaruhnyaterhadap-penggunanya.

Ibrahim, M. S., Ghavifekr, S., Ling, S., Siraj, S., \& Azeez, M. I. K. (2014). Can transformational leadership influence on teachers' commitment towards organizational, teaching profesion and students learning? A quantitative analysis. Asia Pacific Educ. Rev., 15, 177-190. http://dx.doi.org/10.1007/s12564-013-93083.

Juliana, S. (2018). Penerapan Model Pembelajaran Inkuiri Terbimbing Untuk Meningkatkan Hasil Belajar IPA Siswa Kelas VIII Semester II SMPN 5 Siak Kecil Kecamatan Siak Kecil Kabupaten Bengkalis. Jurnal PAJAR (Pendidikan dan Pengajaran), 2 (4), 530-539.

Kurniaman, O., Noviana, O., Pratiwi, S. A., Maharani, D. S., \& Afendi, N. (2020). The Effect Of Smartphone On Student Emotions. International Journal of Scientific \& Technology Research , 9 (01), 138-141.

Kurniaman, O., Hidayat, M. L., Noviana, E., Munjiatun, M., \& Kurniawan, K. (2020). The Validation of LIAA (Linguistic Intelligence Assessment Android) Development In 
Elementary Schools. Profesi Pendidikan Dasar, $\quad 7(2), \quad 162-170 . \quad$ DOI: 10.24036/blbs.v17i1.12696.

Kuntarto, E. (2017). Keefektifan Model Pembelajaran Daring dalam Perkuliahan Bahasa Indonesia di Perguruan Tinggi. Indonesian Language Education and Literature, 3(1), 99-110. 10.24235/ileal.v3i1.1820.

Loo, S-C., \& Ling, Y-L. (2018). Transformational leadership as a predictor towards job satisfaction among form six teachers in Sarawak. International Journal of Education, 11(1), 1-5. doi: http://dx.doi.org/10.17509/ije.v11i1.11087.

Leithwood, K. A., \& Mascall, B. (2008). Collective leadership effects on student achievement. Educational Administration Quarterly, 44(4), 529-561.

Ling, Y. L., Abdullah, K. A. G., \& Ismail, F. (2015). Feedback environment and job motivation among middle leaders of educational organizations. Journal of Education and Training, 3(1), 90-105.

Miller, P. C. (2005). Narratives from the classroom: An introduction to teaching. ThousandOaks, CA: Sage Publications.

Marno. (2007). Islam by Manajement and Leadership. Jakarta: Lintas Pustaka.

Munir, A. (2008). Menjadi Kepala Sekolah Efektif. Jogjakarta: Ar Ruzz Media.

Rambe, M. (2019). Pelaksanaan Supervisi Akademik Sebagai Upaya untuk Meningkatkan Kompetensi Guru dalam Menyusun Rencana Pelaksanaan Pembelajaran. Jurnal PAJAR (Pendidikan dan Pengajaran), 3(4), 782-790. DOI: http://dx.doi.org/10.33578/pjr.v3i4.7464.

Subekti, H., dkk. (2018). Mengembangkan Literasi Informasi Melalui Belajar Berbasis Kehidupan Terintegrasi STEM Untuk Menyiapkan Calon Guru Sains Dalam Menghadapi Era Revolusi Industri 4.0: Revieu Literatur. Education and Human Development Journal, 3 (01), 81-90.

Sadikin, A., \& Hamidah, A. (2020). Pembelajaran Daring di Tengah Wabah Covid-19. BIODIK: Jurnal Ilmiah Pendidikan Biologi, 6(02), 214 -
224.

Doi:

https://doi.org/10.22437/bio.v6i2.9759.

Witherell, C., \& Noddings, N. (1991). Stories lives tell: Narrative and dialogue in education. New York: Teachers College Press.

Zhang, D., Zhao, J. L., Zhou, L., \& Nunamaker, J. F. (2004). Can e-learning replace classroom learning? Communications of the ACM. https://doi.org/10.1145/986213.986216.

Zuriah. (2003). Penelitian Tindakan dalam Bidang Pendidikan dan Sosial. Malang: Banyu Publishing. 